\title{
Prevalence of antibodies to Leptospira interrogans serovar hardjo in bulk tank milk from unvaccinated Irish dairy herds
}

\author{
Nola Leonard ${ }^{1}$, John F. Mee ${ }^{2}$, Sylvia Snijders ${ }^{3}$ and Dermot Mackie ${ }^{4}$ \\ ${ }^{1}$ Faculty of Veterinary Medicine, University College Dublin, Belfield, Dublin 4, Ireland. \\ ${ }^{2}$ Teagasc, Dairy Production Research Centre, Moorepark, Fermoy, Co Cork, Ireland. \\ ${ }^{3}$ Faculty of Agriculture, University College Dublin, Belfield, Dublin 4, Ireland. \\ ${ }^{4}$ Veterinary Sciences Division, Stoney Road, Belfast, BT4 3SD, Northern Ireland.
}

Bulk tank milk samples, collected from 347 herds throughout the Republic of Ireland using a sampling frame based on seven milk-recording organisations, were tested by ELISA for antibodies to Leptospira interrogans serovar hardjo. These herds, which had not been vaccinated against leptospirosis within the previous five years, were categorised according to their province, milk-recording organisation and size. Two-hundred-and-seventy-three

Key words Cattle, Leptospira, Antibodies, Milk ELISA. herds $(79 \%)$ had a positive ELISA titre. Both the probability of a herd being seropositive and the antibody level in the herd milk sample were affected by the province $(P<0.05$ and $P<0.01$, respectively) and the herd size category ( $P<0.05$ and $P<0.01$, respectively). Larger herds were significantly more likely to have positive reactions and higher mean concentrations of antibody. It was concluded that a high proportion of unvaccinated Irish dairy herds have been exposed to infection with Leptospira hardjo.

Irish Veterinary Journal

Volume 57: 226-23I, 2004

\section{Introduction}

Cattle are maintenance hosts for leptospires belonging to serovar bardjo, of which there are two species: Leptospira interrogans serovar hardjo (prajitno) and Leptospira borgpetersenii serovar hardjo (bovis). Clinical signs of hardjo infection include abortion and milk drop syndrome. Whilst there are genetic, epidemiological and pathogenic differences between the two species, the two microorganisms are indistinguishable by serological tests (Ellis et al., 1988; Pritchard, 1999).

Quinlan (1982) first reported clinical disease associated with $L$. bardjo infection in cattle in the Republic of Ireland; infection in

\section{Correspondence:}

Nola Leonard

Faculty of Veterinary Medicine,

University College Dublin,

Belfield,

Dublin 4,

IRELAND

Tel: +3531716 6179

Fax: +3531716 6185

E-mail: nola.leonard@ucd.ie
Irish dairy farm workers was reported two years later (Colgan $e t$ al., 1984). Since then problems associated with hardjo infection in cattle have been diagnosed regularly in Ireland, the UK and elsewhere (Anon., 1999a,b, 2000, 2001; Guitian et al., 1999; Hassig and Lubsen, 1998; Langoni et al., 1999).

The seroprevalence in Irish cattle is unknown; reported data refer to a decade ago or more. Egan and O'Reilly (1985) reported that 792 of $2,415(33 \%)$ of serum samples collected from suspected cases of leptospiral abortion in cows were positive for anti-leptospiral antibody. In later surveys, 46 of 362 (13\%) and 11 of $247(4.5 \%)$ aborted foetuses submitted for examination in 1987 and 1999, respectively, were positive for leptospiral infection (O'Reilly and Egan, 1988; Anon., 1999c). Those surveys for anti-leptospiral antibodies relied on testing of individual blood samples. However, with the advent of an enzyme-linked immunosorbent assay (ELISA), which can be used on milk samples (Pritchard, 1999), herd screening can now be carried out on bulk tank milk samples.

The objective of this study was to establish the prevalence of antileptospiral antibodies in bulk tank milk samples from unvaccinated dairy herds throughout the Republic of Ireland. 


\section{peer reviewed}

\section{TABLE 1: Milk recording organisations participating in a herd survey of anti-leptospiral antibody in bulk tank milk, the target number of herds to be sampled, and the actual number of samples received from each organisation}

\begin{tabular}{|c|c|c|c|c|c|}
\hline \multirow[t]{3}{*}{$\begin{array}{l}\text { Milk recording } \\
\text { organisation }^{1}\end{array}$} & \multicolumn{5}{|c|}{ TARGET } \\
\hline & \multicolumn{4}{|c|}{ Herd size } & \\
\hline & $10-30$ & $31-60$ & $61-99$ & $>100$ & All herds \\
\hline DG & 48 & 35 & 14 & 3 & 100 \\
\hline PG & 46 & 54 & 19 & 6 & 125 \\
\hline SWS & 26 & 19 & 8 & 2 & 55 \\
\hline K & 26 & 19 & 8 & 2 & 55 \\
\hline GV & 11 & 9 & 4 & 1 & 25 \\
\hline NECBS & 20 & 4 & 1 & 0 & 25 \\
\hline NCF & 8 & 2 & 0 & 0 & 10 \\
\hline TOTAL & 185 & 142 & 54 & 14 & 395 \\
\hline
\end{tabular}

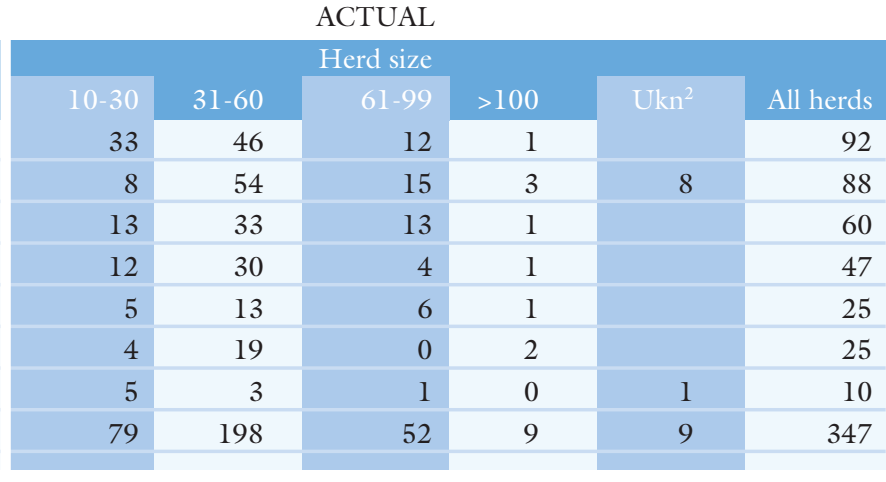

${ }^{1}$ DG $=$ Dairygold Ltd; PG $=$ Progressive Genetics; SWS $=$ South Western Services; K = Kerry Agribusiness; GV = Golden Vale; NECBS = North Eastern Cattle Breeders Society; NCF $=$ North Connacht Farmers Co-op Society Ltd.

${ }^{2} \mathrm{Ukn}=$ unknown.

\section{Materials and methods}

\section{Sampling frame}

Only herds that had not been vaccinated against leptospirosis during the previous five years were selected. Samples were collected through the Irish Dairy Records Company and their associated co-operative milk-recording organisations, based throughout the Republic of Ireland (Figure 1). The sample frame was stratified according to milk-recording organisation and herd size category (Table 1). Numbers of samples to be collected in each herd size category were calculated using data from the Central Statistics Office Census of Agriculture, 1991, which comprised the most recent data available, on farms classified by number of dairy cows in each province.

Personnel from seven milk-recording organisations collected bulk tank milk samples from 347 milk-recorded herds in 22 counties, between May and September 2000.

\section{Milk sampling and analysis}

The bulk tank milk samples were preserved with bronopol (Broad Spectrum Microtabs 2, D\&F Control Systems Inc. Ireland) and stored at $2^{\circ}$ to $8^{\circ} \mathrm{C}$ before analysis by the Ceditest $^{\mathrm{TM}}$ ELISA (Bercovich et al., 1990). Optical density readings equivalent to $60 \%$ or greater of a positive standard $\left(\mathrm{OD}_{450}\right.$ of standard $\left.\geq 1.00\right)$ were considered positive. Results were expressed as percentage positivity of the standard.

\section{Statistical analysis}

Logistic regression was used to determine the effects of province and milk recording organisation in the presence of herd size category and their two-way and three-way interactions on the probability of a herd having a positive antibody result (dichotomous outcome variable) and on the antibody titre

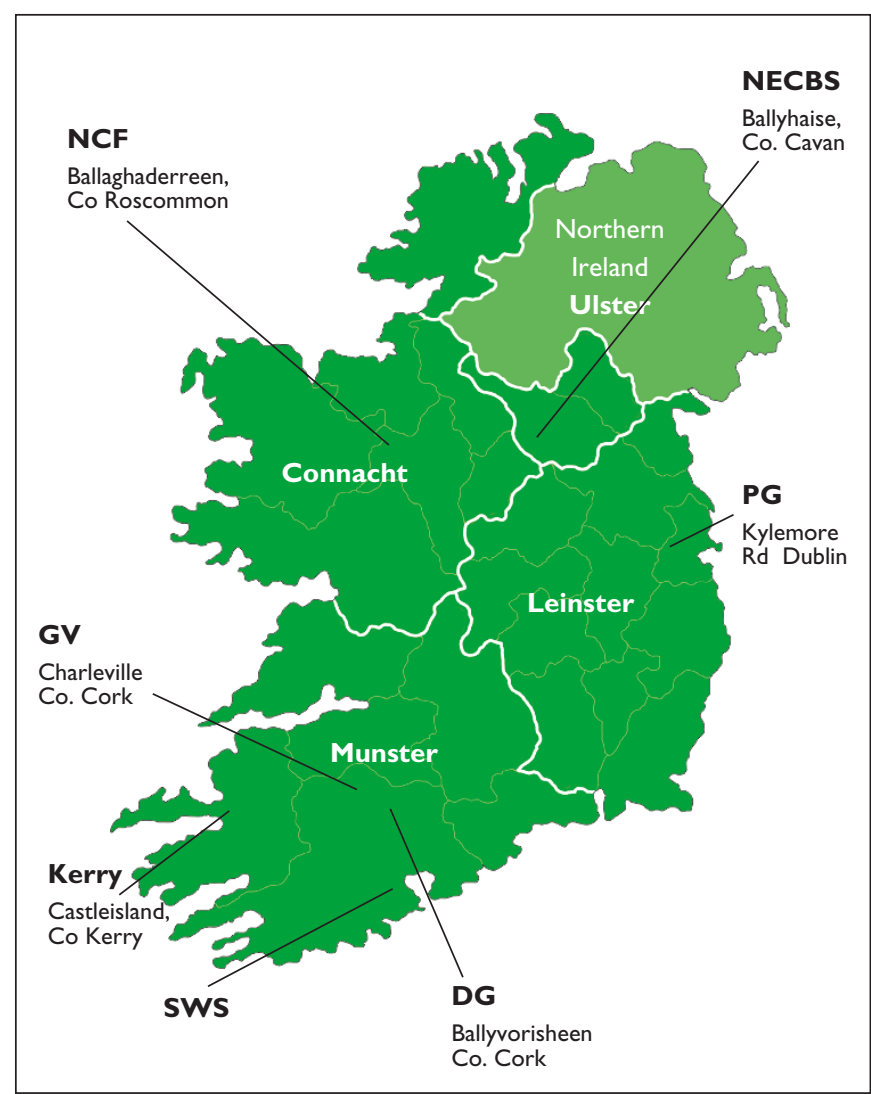

FIGURE I: Location of the seven milk-recording organisations within the four provinces of Ireland that participated in a survey of anti-Leptospira antibodies in bulk tank milk. DG = Dairygold Ltd; GV = Golden Vale; Kerry = Kerry Agribusiness; NCF = North Connacht Farmers Co-op Society Ltd.; NECBS = North Eastern Cattle Breeders Society; PG = Progressive Genetics; SWS = South Western Services. 


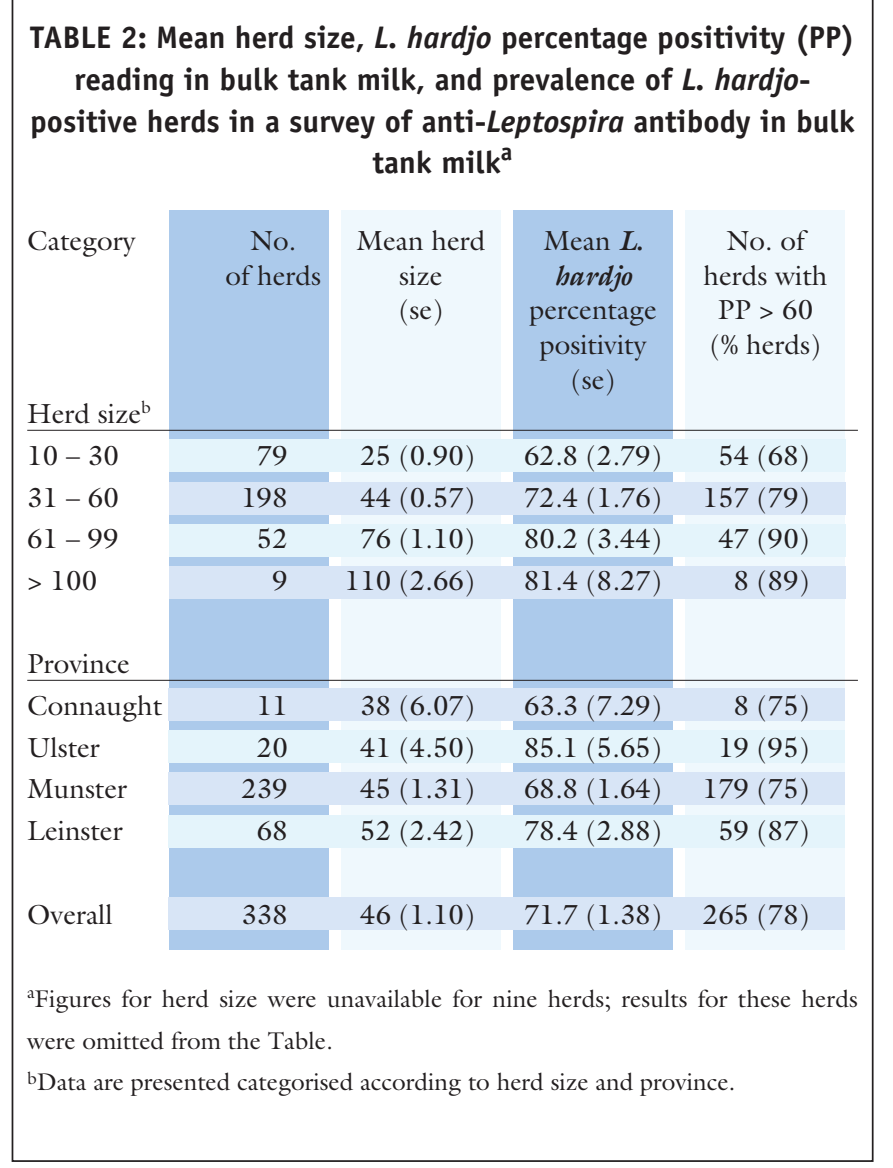

(continuous outcome variable). The relationship between the continuous variables, herd size and antibody level, was examined using the Spearman correlation coefficient. Statistical analyses were performed using the software procedures (PROC GENMOD, PROC CORR) contained in the SAS package (version 8.0; Statistical Analysis Systems Institute, 1999).

\section{Results}

The mean number of lactating cows per herd was $46(\mathrm{sd} 20)$, with a range of 10 to 150 cows. A positive ELISA antibody result was detected in 273 herds (79\%). Detailed results on prevalence of $L$. hardjo-positive herds categorised according to herd size and province are presented in Table 2. Both the probability of a herd being seropositive and the antibody level of the bulk tank milk sample were affected by the province $(\mathrm{P}<0.05$ and $\mathrm{P}<0.01, \mathrm{df}=3, \mathrm{~F}$ value $=4.73$, respectively $)$ and the herd size category $(\mathrm{P}<0.05$ and $\mathrm{P}<0.01, \mathrm{df}=3, \mathrm{~F}$ value $=4.69$, respectively). Herds in the north and east (Ulster and Leinster) were more likely to have a positive titre $(78 / 88$ herds) or a high titre. In addition, large herds ( $>60$ cows) were more likely to have a positive titre $(55 / 61$ herds $)$ or a high titre. Milk recording organisation was not significant $(P>0.05, d f=6, F$ value $=1.29)$ in the presence of these two variables. There were no significant interactions between province, milk recording organisation and mean herd size. There was a positive correlation between mean herd size and mean herd antibody levels $\left(\mathrm{r}_{\mathrm{S}}=0.27, \mathrm{P}<0.0001\right)$.

\section{Discussion}

This is the first survey of leptospiral infection in dairy herds in the Republic of Ireland, which is representative of unvaccinated herds throughout the country. Previous surveys were biased in that they were carried out by questionnaire (without confirmatory laboratory tests), or in selected herds, or on samples selected from herds with a history of abortion. The survey provides useful data, because herds were distributed throughout the country and were sampled in proportion to the number of dairy herds in each region. As the majority of dairy herds are situated in the south and east of the country, the number of samples collected from these areas was much greater than from the west and north. Samples were collected during the summer months, as the majority of the herds were springcalving and thus the bulk tank milk was representative of all lactating cows in the herd. It was not possible to obtain the disease history of herds sampled, but the milk recording organisations were asked to select herds for inclusion at random from their non-vaccinating clients. Thus, although some herds may have been experiencing clinical leptospirosis at the time of sampling, the survey is different from previous surveys of herds with abortion problems. It provides information on the prevalence of anti-leptospiral antibodies in a wide sample of unvaccinated Irish herds, although it is not a random survey of all Irish dairy herds because only herds participating in a milkrecording scheme were included.

Interpretation of infection status of herds with positive results in the Ceditest ${ }^{\mathrm{TM}}$ used in this survey is not possible. A positive result indicates exposure of animals in the herd to infection, but there are no published data available at present, which allow correlation of antibody level with the probability of active versus chronic infection in the herd. Pritchard (1999) divided herds into four categories of infection based on OD ratios obtained in a modified version of the Ceditest ${ }^{\mathrm{TM}}$, but it is not possible to extrapolate his work to the study reported here. Nevertheless, the results reported here confirm that exposure to infection is widespread in unvaccinated Irish dairy herds.

The results of this survey are in broad agreement with previous Irish surveys (Egan and Nolan, 1994; Leonard, 1989; O'Reilly and Egan, 1988; Egan and O'Reilly, 1985). There are few figures available from other countries which are directly comparable to those reported here, as either the sampling methods or the tests used were different. Figures from the UK suggest that between $50 \%$ and $60 \%$ of herds tested with a bulk tank milk ELISA had evidence of active infection, but the figures may have been biased by herds experiencing clinical disease (Pritchard, 1999). A recent survey of the prevalence of antibodies to Leptospira hardjo in bulk tank milk samples found that approximately one-third of herds in France (157 of 452: 


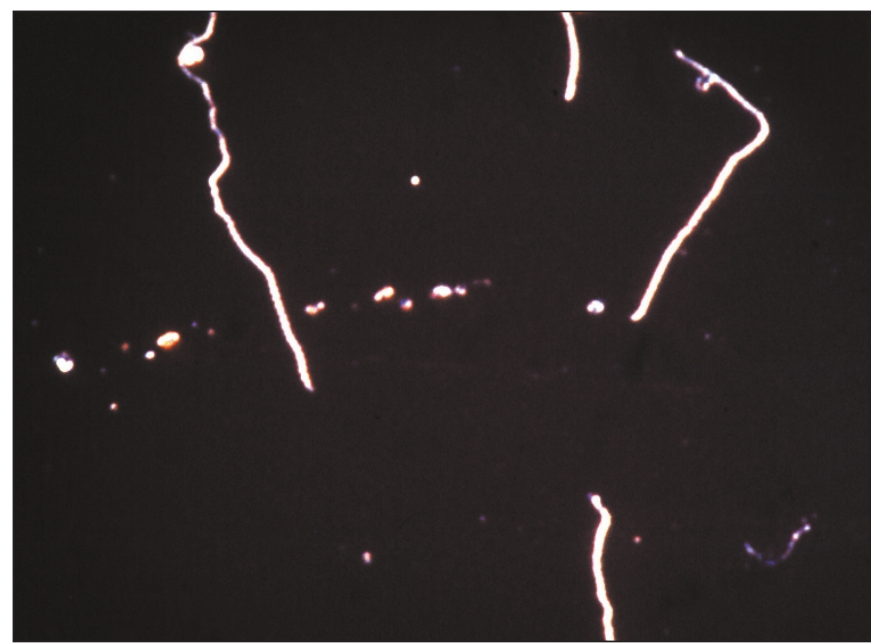

Leptospires growing in culture, demonstrated by darkfield microscopy. $x 1000$. Culture of leptospires is difficult and serological methods, such as ELISA, are used much more frequently for diagnosis.

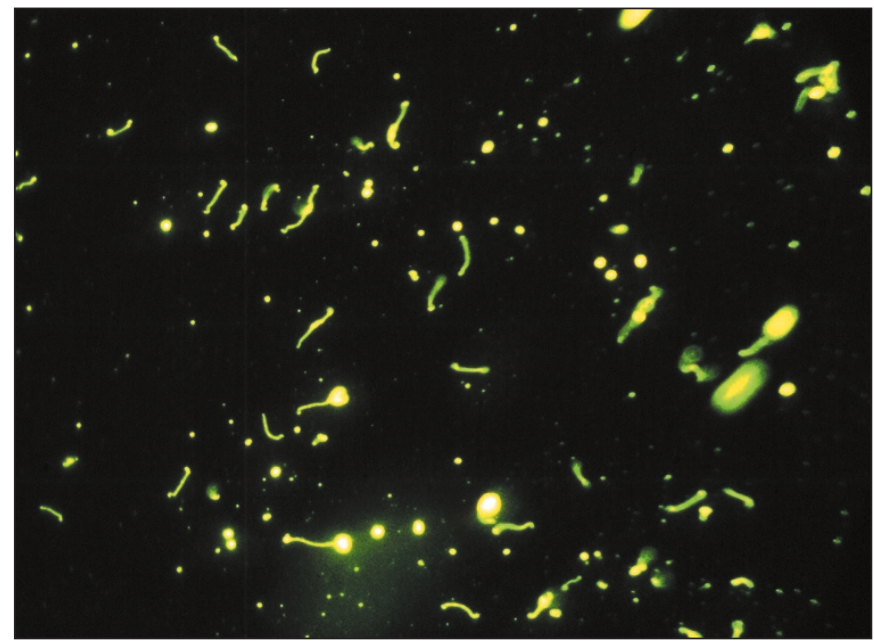

Serovar hardjo demonstrated using immunofluoresence in a bovine urinary deposit. Transmission of infection to animals and man occurs principally through urine splashes.
35\%) and Germany (178 of 490: 36\%) were positive (Wiseman et al., 2002). One or more animals were seropositive to bardjo in 23 of $215(11 \%)$ herds tested in Spain in 1997 (AlonsoAndicoberry et al., 2001). Reasons for the higher proportion of Irish herds with evidence of exposure to infection by hardjo compared to some other European countries are unknown but may be related to the higher cattle density and more frequent movement of cattle between herds in Ireland. A study conducted in the mid-1990s showed that half of 48 intensively managed dairy herds in Munster had recently introduced animals into the herd (Leonard et al., 2001), a known risk factor for leptospiral infection (Pritchard et al., 1989).

An apparent higher prevalence of infection in herds in Ulster may reflect the high reported incidence of clinical problems with leptospirosis in the north of Ireland (Ellis et al., 1985). Herds in Ulster and Leinster are generally housed for longer during winter, with earlier housing in the autumn and later turnout to pasture in the spring, due to lower grass growth rates. This longer period of close contact between cows in herds in these provinces may increase the risk of maintenance and transmission of leptospires and, hence, result in a higher herd milk seroprevalence in these provinces. The data in Table 2 show that the effect of province was independent of the effect of herd size. Regional variation in prevalence has been reported in other studies: in Switzerland (Corboz et al., 1987), Australia (Elder et al., 1986), Italy (Autorino et al., 1997) and the USA (Miller et al., 1991). These authors reported that regional differences were associated with a range of factors including soil type, mean temperature and herd management practices. A study by Autorino et al. (1997) is the most comparable to the study reported here as bulk tank milk samples were tested from herds in a number of Italian provinces. Herd prevalence ranged from
45 of $916(5 \%)$ herds to 183 of 1,000 (18\%) herds, depending on region. Differences in prevalence were attributed to differences in husbandry practices. A detailed epidemiological study would be required to determine the factors affecting herd prevalence in Ireland.

The fact that fewer small herds were positive for anti-Leptospira antibody in milk is not surprising. Exposure to infection is more likely to occur in animals in large herds as infection can be transmitted more easily and persist for longer in larger intensive herds (Agaev, 1992; Thevenon et al., 1990). Positive association between herd size and presence of positive animals has been reported previously for hardjo infection in cattle and for bratislava infection in sow herds (Lilenbaum and Santos, 1996; Mousing et al., 1995; Ellis, 1994) In contrast, a significant association between herd size and hardjo infection was not detected in a survey of dairy and beef herds in Spain (Alonso-Andicoberry et al., 2001).

The prevalence of infection in Irish dairy herds has significant implications for both animals and humans. There is recent evidence from a number of countries that hardjo continues to cause substantial reproductive losses in cattle through abortion (Anon., 2000a, 1999b; Langoni et al., 1999; Hassig and Lubsen, 1998) and infertility (Guitian et al., 1999). Thus, it is possible that losses in unvaccinated Irish dairy herds may be underestimated. It has been suggested that where vaccination has been discontinued, problems with leptospiral infection recur (Anon., 2001).

In addition to possible losses in these herds due to animal disease, transmission of infection to humans could also occur. Although the number of officially notified cases of leptospirosis in Ireland is small, a recent report by Pate et al. (2000) stated that the mean number of hospital-reported cases of leptospirosis 
in Ireland was 4.9 per million per annum during the years 1990 to 1996. This is approximately five times higher than the incidence in England. The highest incidence of disease was in the South-Eastern Health Board at 10.4 cases per million per annum, almost one-third of which were due to serovar hardjo. A significant association between numbers of cattle and annual incidence of leptospirosis was detected. The findings of the present survey have important implications for the health and safety of farm-staff and, possibly, the potential liability of herdowners.

\section{Acknowledgements}

The authors thank Schering-Plough Animal Health Ireland for financial assistance with this study. The contribution of Linnodee Animal Care Ltd., the Irish Dairy Records Cooperative, Dairygold, Golden Vale, Kerry Agribusiness, North Connacht Farmers Co-op Society Ltd., North Eastern Cattle Breeders Society, Progressive Genetics and South Western Services, is gratefully acknowledged. Finally, the authors are grateful to Dr Gabrielle Kelly and Mr Michael Nolan for assistance with statistical analysis.

\section{References}

Agaev, I.A. (1992). Self-perpetuation of foci of bovine leptospirosis. Zhurnal Mikrobiologii Epidemiologii I Immunobiologii 3: 41-44.

Alonso-Andicoberry, C., Garcia-Pena, F.J., Pereira-Bueno, J., Costas, E. and Ortega-Mora, L.M. (2001). Herd-level risk factors associated with Leptospira spp. Seroprevalence in dairy and beef cattle in Spain. Preventive Veterinary Medicine 52: 109-117.

Anon. (1999a). SAC Veterinary Science Division report. Veterinary Record 144: 516

Anon. (1999b). VLA surveillance report. Veterinary Record 145: 537.

Anon. (1999c). Quarterly report of the regional veterinary laboratories: April-June. Irish Veterinary Journal 52: 614

Anon. (2000). VLA surveillance report. Veterinary Record 146: 561

Anon. (2001). Quarterly report of the regional veterinary laboratories, April-June 2000. Irish Veterinary Journal 54: 123-125.

Autorino, G.L., Barbaro, K., Salvati, F. and Amaddeo, D. (1997). Leptospira hardjo: infection diffusion among dairy cattle in the Latium region. Veterinaria Italiana 33: 20-25.

Bercovich, Z., Taaijke, R. and Bokhout, B.A. (1990). Evaluation of an ELISA for the diagnosis of experimentally induced and naturally occurring Leptospira hardjo infections in cattle. Veterinary Microbiology 21: 255-262.

Colgan, M., Eivers, B. Jr. and Egan, J. (1984). An unrecognised zoonosis?: Leptospira hardjo in man in the Republic of Ireland. Irish Medical Journal 77: 238-240.

Corboz, L., Leisi, U. and Bertschinger, H.U. (1987). Epidemiology of leptospirosis in Switzerland - regional prevalence of antibodies to L. hardjo in the bovine population. Israel Journal of Veterinary Medicine 43: 323-326.

Egan, J. and Nolan, P.D. (1994). A questionnaire survey of Leptospira bardjo infection and its control in dairy herds in the Republic of
Ireland. Irish Veterinary Journal 47: 257-259.

Egan, J. and O'Reilly, P.F. (1985). Antibodies to Leptospira interrogans serovar hardjo in sera from aborting cattle in the Republic of Ireland. Irish Veterinary Journal 39: 143-145.

Elder, J.K., McKeon, G. M., Duncalfe, F., Ward, W.H. and Leutton, R.D. (1986). Epidemiological studies on the ecology of Leptospira interrogans serovars pomona and hardjo in Queensland. Preventive Veterinary Medicine 3: 501-521.

Ellis, W.A. (1994). Leptospirosis as a cause of reproductive failure. Veterinary Clinics of North America: Food Animal Practice 10: 463478.

Ellis, W.A., O'Brien, J.J., Bryson, D.G. and Mackie, D.P. (1985). Bovine leptospirosis: Some clinical features of serovar hardjo infection. Veterinary Record 117: 101-104.

Ellis, W.A., Thiermann, A.B., Montgomery, J., Handsaker, A., Winter, P.J. and Marshall, R.B. (1988). Restriction endonuclease analysis of Leptospira interrogans serovar hardjo isolates from cattle. Research in Veterinary Science 44: 375-379.

Guitian, J., Thurmond, M.C. and Hietala, S.K. (1999). Infertility and abortion among first-lactation dairy cows seropositive or seronegative for Leptospira interrogans serovar hardjo. Journal of the American Veterinary Medical Association 215: 515-518.

Hassig, M. and Lubsen, J. (1998). Relationship between abortions and seroprevalences to selected infectious agents in dairy cows. Journal of Veterinary Medicine. Series B 45: 435-441.

Langoni, H., de Souza, L.C., da Silva, A.V., Luvizotto, M.C.R., Paes, A.C. and Lucheis, S.B. (1999). Incidence of leptospiral abortion in Brazilian dairy cattle. Preventive Veterinary Medicine 40: 271-275

Leonard, N., Egan, J., Griffin, J., Hanlon, A. and Poole, D. (2001). A survey of some factors relevant to animal welfare on 249 dairy farms in the Republic of Ireland. Part 2: Data on incidence of disease, culling and biosecurity measures. Irish Veterinary Journal 54: 454-456.

Leonard, N. (1989). Leptospirosis in cattle - clinical signs and control. Irish Grassland and Animal Production Association Journal 23: 105109.

Lilenbaum, W. and Santos, M.R.C. (1996).Effect of management systems on the prevalence of bovine leptospirosis. Veterinary Record 138: 570-571.

Miller, D.A., Wilson, M.A. and Beran, G.W. (1991). Relationships between prevalence of Leptospira interrogans in cattle and regional, climatic and seasonal factors. American Journal of Veterinary Research 52: 1766-1768.

Mousing, J., Christensen, J., Haugegaard, J., Schirmer, A.L. and Friis, N.F. (1995). A seroepidemiological survey of Leptospira bratislava infections in Danish sow herds. Preventive Veterinary Medicine 23: 201-213.

O'Reilly, P.J. and Egan, J. (1988). Leptospiral and Salmonella abortions and stillbirths in cattle - a survey. Irish Grassland and Animal Production Association Journal 22: 155.

Pate, G.E., Hogan, M.C., FitzSimon, N. and Mellotte, G.J. (2000). A review of the epidemiology of leptospirosis in the Republic of 


\section{peer reviewed}

Ireland. Irish Medical Journal 93: 114-117.

Pritchard, G.C. (1999). Bulk milk antibody testing for Leptospira hardjo infection. Cattle Practice 7: 59-61.

Pritchard, D.G., Allsup, T.N., Pennycott, T.W., Palmer, N.M.A., Wooley, J.C. and Richards, M.S. (1989) Analysis of risk factors for infection of cattle herds with Leptospira interrogans serovar hardjo. Proceedings of a Meeting of the Society for Veterinary Epidemiology and Preventive Medicine, Exeter University, UK. pl30.

Quinlan, J.F. (1982). Perinatal mortality in dairy calves associated with Leptospira interrogans serovar hardjo infection. Irish Veterinary Journal 36: 124-126.

Thevenon, J.G., Lambert, C., Desouter, D., Costa, R. and Domenech, J. (1990). Epidemiological study of bovine leptospirosis in New Caledonia South Pacific ocean. Recueil de Medecine Veterinaire de l'Ecole d'Alfort 166: 903-909.

Wiseman, A., Joris, E., King, V. and Debouck, P. (2002). Prevalence of antibodies to Leptospira borgpetersenii serovar hardjo, as detected by an ELISA test, in samples of bulk tank milk from selected countries in Europe. Proceedings of the XXII World Buiatrics Conference, Hannover, Germany. Abst. No. 162, p50. 